Koukpaki, Serge and Adams, Kweku

ORCID: https://orcid.org/0000-0002-3737-954X (2020) Enhancing professional growth and the learning and development function through reflective practices: an autoethnographic narrative approach. European Journal of Training and Development.

Downloaded from: http://ray.yorksj.ac.uk/id/eprint/4507/

The version presented here may differ from the published version or version of record. If you intend to cite from the work you are advised to consult the publisher's version: https://www.emerald.com/insight/content/doi/10.1108/EJTD-09-2019-0165/full/html? skipTracking=true

Research at York St John (RaY) is an institutional repository. It supports the principles of open access by making the research outputs of the University available in digital form. Copyright of the items stored in RaY reside with the authors and/or other copyright owners. Users may access full text items free of charge, and may download a copy for private study or non-commercial research. For further reuse terms, see licence terms governing individual outputs. Institutional Repository Policy Statement

\title{
RaY
}

Research at the University of York St John

For more information please contact RaY at ray@yorksj.ac.uk 


\section{Emerald $\begin{aligned} & \text { European Journal of } \\ & \text { Training and Development }\end{aligned}$}

Enhancing professional growth and the learning and development function through reflective practices: an autoethnographic narrative approach

\begin{tabular}{|r|l|}
\hline Journal: & European Journal of Training and Development \\
\hline Manuscript ID & EJTD-09-2019-0165.R2 \\
\hline Manuscript Type: & Research Paper \\
\hline Keywords: & $\begin{array}{l}\text { reflective practice, gradual reflective patterns, learning and } \\
\text { development, Training, India, coaching and mentoring }\end{array}$ \\
\hline \multicolumn{2}{|l}{} \\
\end{tabular}


Enhancing professional growth and the learning and development function through

\author{
reflective practices: an autoethnographic narrative approach
}

\begin{abstract}
Purpose - This paper seeks to explore ways in which learning and development (L\&D) professionals use reflective practice to promote the function of $L \& D$ and their own professional growth. The claim that $L \& D$ practitioners need to develop their reflective ability to make sense of their own practice is well-argued in the literature, but few studies focus on an in-depth individual self-reflection and its impact on professional growth.

Design/methodology/approach - An autoethnography and reflective practice design was deployed. The data was collected by sending a semi-structured, pre-set question as a reflective conversation' to an L\&D manager and a ten-hour tape recording of personal reflection over three months. Data was sanitised, transcribed and edited, and a narrative data analysis method was used to analyse the data developed into reflective narratives.

Findings - We find that reflective practice emerges through gradual reflective patterns that define the circumstances surrounding the reflection, the content, exploration and interpretation, and confirming the fulfilling of the reflection.

Originality/value - This paper offers the journey of an L\&D manager working in the hotel industry in India. Through a set of reflective practices, including introspection and reflexivity, the manager considers the changes she has experienced. The paper contributes to the literature on reflective practice based on promoting the L\&D function as an essential part of the horizontal integration of human resource management in organisations. Theoretical and practical implications are discussed.
\end{abstract}

Paper type - Empirical paper

Keywords: reflective practice, learning and development, gradual reflective patterns

\title{
Introduction
}

Advocates of learning and development (L\&D) argue for multiple methods to develop competencies and capabilities in organisations (Garavan, 1991; Mayo, 2003; Boydell and Leary, 2003; Swanson, 2009; Nansubuga et al., 2016). Amongst others, they promote training, mentoring, coaching, facilitation and 360-degree feedback at the individual level. The review 
suggests that few papers promote the reflection and reflective practices as development and professional growth methods for the L\&D professionals.

The literature review indicates that most papers were conceptual-type papers dealing with issues such as epistemology of practice (Raelin, 2007), critical reflection, reflexivity and confessional turns (Swan, 2008), case study-type papers (Sambrock and Stewart, 2008; Francis and Cowan, 2008) examining, respectively, issues such as fostering an action-reflection dynamic amongst student practitioners developing critical reflection in professional focused doctorate-facilitator perspectives (Rigg and Trehan, 2008). Investigating critical reflection in the workplace is just difficult! The research-type papers were still rare apart from Stewart et al.'s (2008) research on postgraduate education to support organisational change that is 'reflection on reflection'. Besides, none of these studies focused on L\&D professionals. Furthermore, the review-type papers did not focus on L\&D professionals. Table 1 critically evaluates these literatures, and we draw out the implications for our study.

\begin{abstract}
Insert table 1 about here
This study examines the reflective journey of an L\&D professional over three months and we sent out a pre-set, semi-structured interview schedule to capture her reflection on her career journey and how she uses reflection to promote her career and the L\&D function, which is still considered as a 'mere' training in her context. In doing so, we pose the following research question: In what ways does reflective practice improve this L\&D professional's growth and the L\&D function?
\end{abstract}

Schön (1983: 61-78) has written extensively on the relationship between reflection and professionalism. He maintains that

'A professional practitioner is a specialist who encounters certain types of situations again and again ... He develops a repertoire of expectations. He learns what to look 
for ... As long as his practice is stable, in the sense that it brings him the same types of cases, he becomes less and less subject to surprise ... As practice becomes more repetitive and routine ... the practitioner may miss important opportunities to think about what he is doing. He may be drawn into patterns of error which he cannot correct ... When this happens, the practitioner has over-learned what he knows'.

We argue that L\&D professionals in their professional practice may sometimes miss important opportunities to think about what they are doing, and reflection time might help them improve their professional status and their career trajectory.

Reflective practice is well-embedded in the context of education, for example, in initial teaching education (Clarà, 2015; Walshe and Drive, 2019; Farell, 2019), health, nursing, social care, and in medicine (Vollbrecht and Bowerman, 2004; McIntyre et al., 2019), where students must demonstrate how their learning is both informed by theories and their practices. Messmann and Mulder (2015) investigated the role of the reflector as a preparatory mechanism for employees' engagement in innovative work behaviour (IWB) and concluded that teachers' IWB strongly depended upon work tasks, whilst social context affected teachers' IWB indirectly by positively impacting their performance-related reflection. They proposed that reflection should be valued as a resource for innovation and professional development, as well as a vital component of work routines, organisational cultures and job training.

We begin this paper by reviewing the literature on learning and development as a professional function, and therefore, L\&D managers as professionals; we then deconstruct the concept of reflective practice and examine its components. We introduce the methods of the study, consider the implications of this paper upon the wider literature and identify the potential for further research. 


\section{Literature Review}

\section{L\&D as professional function and L\&D managers as professionals}

Harrison (2009) argues that the essence of L\&D as an organisational process is to aid collective progress through the collaborative, expert and ethical simulation and facilitation of learning and knowledge that support business goals, develop individual potential and respect and build on diversity. An effective L\&D strategy of an organisation explicitly states how the organisation plans to develop the capabilities, skills and competencies of its employees to be competitive in its environments but also emphasises partnership and ethical behaviour. L\&D is a function that contributes to the attainment of strategic organisational objectives, providing the mechanism for knowledge creation and exchange (Crawshaw et al., 2017). Crawshaw et al. argue that the L\&D function has been recognised as one of the core functions of the Human Resource (HR) function.

\section{Professionalism and $L \& D$}

There are various ways to conceptualise professionalism. Zibrik et al. (2010) indicate that professionalism is concerned with conduct, goals and qualities that designate someone as professional. Ghadiran et al. (2014) maintain that professionalism carries the importance of acquiring a professional ideology, measured by the best standards. Professionalisation is, therefore, a process by which individuals, organisations and systems receive accreditation or become a professional association. These processes are defined to include specialised training and skills, exclusivity, complexity, code of ethics, gaining specific credentials, and establishing professional-client relationships (Abbott, 1991; Lawrence, 1999). Vollmer and Mills (1966: 19) suggest that professionalisation is a process with a "predictable sequence in the way in which occupations assume the attributes of a profession'. 
We propose that a professional has standards of work, encourages collegiate control, has $a$ privileged position and lays special claim to a particular body of knowledge and/or set of technical competencies. In addition, a professional has a status, power and control. Based on this definition, we could claim that L\&D practitioners are professionals since they have adopted standards of work in the fields of training, development learning, coaching and mentoring; they promote collegiate control, and they lay exclusive claim to a particular body of knowledge and develop a set of technical competencies that are embedded in the human resource development curriculum. Indeed, the professionalisation of the human resource function in the UK Chartered Institute of Personnel and Development (CIPD) has enhanced the status of the HR profession, including the L\&D function. These professionals possess specialist knowledge and skills based on a particular education and training, which is claimed to help clients tackle and solve the problems they face. Whilst the L\&D professionals have benefitted from enhanced status in the developed world through the influence of professional bodies, it is often not the case in India and South East Asia, where the function is still considered as a 'mere' training function. This could be explained by the lack of two important components that characterise a profession: professional values (in particular, moral integrity) and professional identity (created by a common identity with the professional community and sense of loyalty to fellow practitioners; Evetts, 2003).

According to Tarrant (2013: 3), being a professional is about much more than 'what you do. It is also about how you do it and the values that go along with it. It is about how you behave; it is about who you are and how you see yourself'. He further maintains that in the process of talking about our profession and articulating some of these deep-seated beliefs and values in terms of professional practice, we might begin to better understand them. It is from this perspective that we seek to encourage an L\&D professional to reflect on her practices. We would, therefore, argue that for senior managers in India to start appreciating L\&D as a 
professional function, and L\&D practitioners as professionals, a set of professional values and professional identity that transcends one industry is required.

In this regard, Schön's (1983: 78) definition of professional practitioner fits well. 'That a professional practitioner is a specialist who encounters certain types of situations again and again. The professional develops a repertoire of expectations and learns what to look for. As long as his practice is stable, in the sense that it brings him the same types of cases, he becomes less and less subject to surprise. But as a practice becomes more repetitive and routine, the practitioner may miss important opportunities to think'. This definition assumes three important characteristics including professional expertise, professional autonomy and professional accountability. Professional expertise assumes a continuous development which enables the expansion of the language repertoire of expectations by constantly updating one's knowledge and expertise. In contrast, professional autonomy seems a long stretch in the formal organisational environment but might help the L\&D manager apply rigour and robust standards for achieving the objectives of the organisation. Finally, professional accountability assumes that there is a code of professional conduct the L\&D manager is expected to adhere to. Whilst practitioners perceive their role as 'ethical stewards' in challenging unethical organisational practice, they do not always follow through in their actions (CIPD, 2017). Hence, the CIPD argues for six core elements of professionalism to include social and ethical responsibility, body of knowledge and skills, situational judgement, commitment, continuous professional development (CPD) and identity.

The CIPD also maintains that ethical responsibility uses knowledge for the good of society (Khurana et al. 2004) and that expert knowledge and skills are based on specialised learning and education (Gilmore and Williams, 2007), that situational judgement helps to apply expertise to specific circumstances (Arnold and Stern, 2006), commitment is toward the clients served. More importantly, CPD requires a regular update of expert knowledge and investment 
in the maintenance of professional skill (Gilmore and Williams, 2007). It is through CPD that practitioners are provided with the opportunities to reflect on their professional practices and approach to fulfilling the function.

\section{Reflective practice}

There are several definitions of reflective practice. On the one hand, Lucas (1991) proposes a valuable definition when he suggests that it involves a systematic inquiry to improve and deepen understanding of the practice. Within this definition, the word 'systematic' implies that reflective practice is carried out in a logical, methodical or orderly manner. On the other hand, Bolton and Delderfield (2017: 1) maintain that reflective practice is a critical enquiry into any aspect of our practice, deepening and clarifying our understanding of it and our relationship with it. An important aspect reflection is reflexivity, which is concerned with critical selfreflection. Furthermore, the authors propose that reflection is a process of 'focused thinking' about anything, and it is an in-depth review of events. This enables the practitioner to find routes through difficulties, dilemmas and decision making. It focuses upon one's actions, thoughts, hopes, fears, roles, values and assumptions to gain insight into them.

Besides, Bager-Charleson (2010) asserts that reflexivity develops responsible and ethical action, such as becoming aware of how much our ways of being are culturally determined since other people have very different expectations and norms. Johns (2017) defines reflexivity as 'looking back' to see self-becoming in the sense of realising desirable practice set against an analysis of forces that have constrained the reflector, evidenced through a chain of experiences whereby one link of the chain leaves a thread that is picked up and developed by next link (Dewey, 1993). Recently, McCray et al. (2018) maintain that reflexivity is a practice of 
thinking critically about actions related to others and paying attention to the ways in which we come to envisage future practice.

We examine in this paper the reflector in both reflection-on-experience and reflection-in-action and draw out the implications for the promotion of the L\&D function, as well as the career journey of the reflector. If reflection-on-experience is concerned with looking back on 'an experience' (Johns, 2017), then reflection-in-action appears to be sub-divided into reflectionon-action and reflection-in-action (Schön, 1983, 1987). Reflection-in-action occurs whilst the novice is in the midst of an activity. On the other hand, reflection-on-action happens after the novice has completed the action (encounter). Both types of reflections are said to be timedependent. In this study, the questions asked to the reflector (research subject) are timedependent. For example, the impact of personal learning and career progression on the L\&D function are time-dependent.

Others, such as Brookfield (2009), propose the concept of 'critically reflective practice' that encapsulates the descriptions of specific events or experiences. He defines critical reflection as 'a deliberate attempt to uncover, and then investigate the paradigmatic, prescriptive and causal assumptions that inform how we practice' (2009:125-6). Thus, critical reflective practice inherently implies a reflection on experience but also focuses on the critique of the approach used in the reflection. We intend to carry out analysis at an individual level in order to understand how the subject of this study presents her paradigmatic assumptions, or her 'worldviews' concerning her wider learning, personal learning, career development planning, approach to change management, and how each of these assist her in demonstrating the added value of the function she manages in an environment where learning and development is considered as a 'mere' training function. 
We agree with the idea of Rigg et al. (2008: 321), who maintain that critical reflective practice 'is a broadly interpreted term with meanings that range from questioning assumptions and presuppositions through to more explicit engagement in a process of drawing from critical perspectives to make connections between learning and work experiences. This is done to understand and ultimately change personal, interpersonal and organisational practices. It appears that the notions of uncovering, and then investigating as suggested by Brookfield (2009) might also be said to be 'systematic', or in other words, logical. Many criticisms against the concept of reflective practice have also been brought forward. For example, Bassot (2016) proposes that it is evident we think about practice, and so discounts the notion of doing it consciously, whilst others point to the difficulties practitioners experience in trying to take a reflective approach to busy professional lives (Finlay, 2008).

Critical reflective practice is also underpinned by reflexivity. Bassot (2016) suggests that in professional practice, reflexivity means we are aware of how we think, feel, and act and the assumptions we might be making. Also, reflexivity brings an awareness of issues of power in relationships in organisations. Fook and Askeland (2006) assert that reflexivity also involves being aware of our context and the impact this can have on our practice. Critical reflective practice requires three important aspects, as argued by Fay (1987), and these are curiosity, commitment and intelligence. In this paper, we interrogate these three aspects by examining the power of the narrative. Narrative is the form people use to make sense of events and relationships. Reflective practices are based on narratives of experience, often stories about specific incidents (Bolton and Delderfield, 2017). This paper adopts the autobiographical narrative of one L\&D manager in various professional contexts, with consideration of change, conflict, taking care, a moment of joy, frustration, missed opportunity, the desire to succeed, and an evocative occasion. 
This research does not set out to use a particular framework for the reflection of the L\&D manager (the reflector). The literature on reflection suggests that many frameworks allow the reflector to methodically do the refection. For example, Mezirow (1981) develops content reflection which helps the practitioner explore the problem to better understand it. Boyd and Fales (1983) also create six components of reflection based on counsellor reflection. Whilst Boud, Keogh and Walker (1985) presents the three-stages model, Gibbs' (1988) model focuses on a single event, its consequences and possible development. A relatively more recent model by Smith et al. (2015) proposed a four-step model for reflection titled DATA: (D)escribe, (A)nalyse, (T)heorise and (A)ct.

This research uses abstract management theory, the conceptualisations that are applicable to managing and organising, in order to narrate the research subject's career development path, personal learning and the impact of the L\&D function. The study also examines the tacit knowledge relevant to managing, which is usually a combination of abstract theory and practical understanding, which guide actions. Theory-in-use, the tacit knowledge that is brought to bear upon actions is also considered. Theory-in-use is intuitive and otherwise internalised, but if it could be extracted, it would be an expression of how the reflector perceives the world. Thus, an extracted theory in use would communicate to outsiders something about how the reflector understands things to function, what the outsiders see as taken for granted. It is this knowledge that influences how the reflector acts and carries out her job.

\section{Methods}

Context

The subject of this research is an L\&D manager working in the hotel industry in India with over 15 years of work experience. Her role entails managing the function for the unit hotel 
along with the L\&D initiatives for India region. Moreover, she line-manages 12 L\&D managers at several hotels in India. She reflects on her roles and responsibilities and how these shapes the delivery of the services she provides and the challenges she faces to ensure that the L\&D function is highly regarded and prominent within the organisation. As the narrator of this reflection, she has a critical role in the stories; her perceptions of self, society and culture become preponderant in the narration (Bolton, 2009).

\section{Study design}

The research deployed an autoethnographic and reflective practice approach rooted in personal narratives seen as stories that provide accounts of lives and events as told by or from the perspective of the narrator (Laslett, 1999). These accounts focused on collecting data on behaviours and perceptions that occur during the answer of the pre-set, semi-structured questions and the tape recording over three months. The emphasis was to explore the contextual realities that shaped the growth of the L\&D manager and the impacts she had on the function rather than testing hypotheses (Revees and Kuper, 2008). Indeed, McIntyre et al. (2019) advocate that autoethnography arises from the ethnography tradition but uses the self as source data (i.e. the L\&D manager).

Duncan (2004) argues that autoethnography research is case studies that follow ethnography research and is therefore adequately a justifiable design strategy that allows the development of emergent central themes. However, he adds that autoethnography presents few 'shortcomings (that) include overreliance on the potential of a personal writing style to evoke direct emotional responses in readers but offer no deeper levels of reflection or analytic scholarship; lack of self-honesty and disclosure about the motivation for doing the research, resulting in the misuse of the role of author to justify actions or advocate the interests of a particular group' (p.5). We argue that personal experience methods are said to offer a new and 
unique vantage point from which to contribute to social science by considering 'macro and micro linkages; structure, agency and their intersection, [and] social reproduction and social change' (Laslett, p. 392). It is in that sense that we can extrapolate her reflection on personal professional growth and the impact it has on the L\&D function in her context.

\section{Participant and sampling}

Deriving from the above design and following the suggestion of Reeves and Kuper (2008), the participant was sampled on an opportunity and purposive basis. We acknowledge the difficulties of employing critical reflection within the workplace (Rigg and Trehan, 2008), but more so to the size of the sample strategies. We do not claim an external generalisation in this paper (Brunt et al., 2017; Mason, 2018; Poth, 2018). Indeed, (Gillham, 2000) suggests that the main purpose of a case study is to provide evidence to support the claims one is making. (Gillham, 2000, p. 4). offers the following explanation:

A case, therefore, can be an individual: it can be a group such as a family or a class, or an office. Or a hospital ward; it can be an institution-such as a children's home, or factory, it can be a large-scale community.

In this research, our case is a single L\&D professional. We adhere to Gillham's advice that: (a) one needs to be organised by sorting out types of evidence; and (b) one must be alert to the need for multiple sources of evidence (in our case, we use two methods to collect the data). 'This does not mean talking to a lot of different people (although you should do that, and crossreference), but you should look at different kinds of evidence such as what people say, and what you see them doing, what they make or produce and what documents and records show' (Gillham, 2000, p. 4). We achieved this by pointing out in the data collected a set of reflective practices, including reflection and reflexivity as the L\&D manager considers the changes she has experienced. 


\section{Data collection}

It was more advantageous for reflection to be carried out via two methods: first, semi-structured questionnaire reflective writing. To facilitate such an approach, the L\&D manager was sent pre-set, semi-structured questions (Vollbrecht and Bowerman, 2004) to explore the multidimensional aspects of her roles and responsibilities. We were interested in questioning, as, according to Bolton and Delderfield (2017: 31) 'questions determine directions, and what might be discovered, rather than destinations. Findings beget more questions. This nonjudgemental critical process is active and enquiring, rather like the wise child's eternal Why?' This helps in understanding the underlying assumptions about how the research subject reveals her whole self to the reflective practice, including potential vulnerabilities and strengths.

Second, the L\&D manager was encouraged over three months in a total of ten hours to record her daily salient reflections. These recordings were sanitised and aligned with the pre-set, semistructured interview schedule to develop the reflective narratives.

\section{Reflective narrative development}

Autoethnographic and reflective methods were adopted in developing reflective narratives. Laslett (1999) indicated that 'personal narratives provide a unique perspective on the intersection of the individual, the collectivity, the cultural, and the social. As an analytic technique and source, they can access motivation, emotion, imagination, subjectivity, and action in ways less available from other sources. They also provide a unique way to understand history because the narrative form incorporates the passage of time into the analytic frametemporality is an inevitable dimension of life histories' (p.392). 


\section{Data analysis}

Narrative analysis was deployed to the elicitation of the sense of temporal sequence that people, as tellers of stories about lives or events around them, detect in their lives and surrounding episodes and inject into their accounts (Bryman, 2008). According to Ryan (2007: 24) 'whilst narrative is about problem-solving' it is also about conflict and interpersonal relations, the human experience and more importantly, the temporality of existence'. In a related study, Laslett (1999:392) argues that to call a personal narrative a story is not to call it a fiction'. In this study, the personal narrative comes in the form of autobiography in terms of education, professional experience, current roles and responsibilities, struggles through change at work, impact on the L\&D function, managing politics, learning to be a better manager and professional status. These were derived from the pre-set, semi-structured interview questionnaire and the tape recording that was transcribed.

Therefore, we examined the professional, political or strategic dimensions of her life stories and their analysis; the interviews and tape recording were used to construct her professional life histories and present an unmediated reflection of social personal life. The analytic stage of the narrative focuses on temporality and plot to look at the storied nature of the reflection experience. We draw on the following: narrative as problem-solving, narrative as conflict and interpersonal, narrative as human experience and narrative as temporality and plot (Ryan, 2007).

In answering our initial research question, 'In what ways does reflective practice improve this $L \& D$ professional's growth and the L\&D function?' we found that the L\&D professional's reflection was directed to the following narrations: personal narrative on her career, professional growth, educational journey, strategic dimensions of change and its impact on professional career, organisational politics, being a better manager, seeing the big picture, and 
the status of L\&D to professional in her context. Therefore, we derive the circumstances of the reflection, the content of reflection, explore the interpretation of the reflection and confirm the fulfilling of the reflection.

\section{Narrative Reflection and Discussion}

\section{L\&D manager's reflection on her career-personal narratives are works of history about an individual}

The researchers sought to understand the broad view of what the role of the L\&D manager is in her current organisation. Thus, by implication, if the function of L\&D is seen as that of a professional, such intention helped to ascertain the context in which the reflection is taking place. Fook and Askeland (2006) assert that reflexivity also involves being aware of context and the impact this can have on practice. Reflective practices are based on narratives of experience, often stories about specific incidents (Bolton and Delderfield, 2017). In the narrative that follows, the L\&D manager self-queries into experience to find meaning and gain insight that deepens her professional experience:

My role focuses on managing $L \& D$ in the India region, with a weak connection with South-East Asia (SEA) functions. Yes, we have been trying to replicate the best practices they have in SEA, as the organisation is a very established brand in that part of the world as compared to India. My key role is to make sure there is support for my 12 L\&D managers in the region (India). I coach, mentor and sometimes even guide them professionally. I make sure their regional objectives are met in terms of training delivery of some of the key programs (leadership development programmes for middlemanagers). I also support new L\&D managers and create a roadmap for them, to make sure they have a buddy within the team who knows their brand well to guide the new L\&D manager into the Learning and Development processes for the organisation. I also co-facilitate a few of the leadership development programmes in India. With my regional manager's support and knowledge of him managing SEA, we are constantly working to change the shape of $L \& D$ in India. $L \& D$ in India is not a very critical function as perceived by others. 
Return on Investment (ROI) for training is not tangible and identified easily. It has been challenging to see clear ROI in terms of numbers, in an industry where it is all about customer experience. Also, the hotel industry moves around revenue numbers and how much gross operating profit is made. L\&D is not a profit centre, or at least not something that can be translated into numbers easily, hence the role of $L \& D$ managers becomes very insignificant.

The current roles and responsibilities of the L\&D manager provide the contextual environment in which she operates and the extent to which her function could be considered as professional.

They also offer a brief explanation as to why the L\&D function continues to be relegated to a lesser professional status. This could be explained by a lack of commitment from senior leaders (CIPD, 2017) and processes such as specialised training and skills, exclusivity, complexity, code of ethics, gaining specific credentials, and establishing professional-client relationships (Abbott, 1991; Lawrence, 1999). It also provides an understanding of how the L\&D manager tries to promote the function's professional status, for example, 'coaching, mentoring, create a roadmap, run leadership programme’ (specialised training skills, Schön, 1983).

\section{The L\&D manager's reflection on her professional growth}

Professional growth involves looking back and recounting lives that are located in particular times and places. Osgood (2006) argues that professional identity is performatively constituted, which is about what practitioners do at particular times, rather than a universal indication of who they are. Indeed, this question takes the L\&D manager back in time to tell what she did in a particular time that led to her current position, that it is the performance.

It happened over a cup of tea while I was planning to resign from my last job. A friend who was an L\&D manager with another hotel company asked me if I would like to come back to the hotel industry, as there is always a lack of good L\&D professionals, and with my credentials, he thought I could add value to the role, and I thought why not give it a try? And that is how I am here doing the job that I love.

I am a hotel management graduate. That's what my undergraduate degree is in, and I wanted to be a wine connoisseur, but finances didn't allow me to study that further, and the next thing I wanted was to be in hotel training. I graduated in 2003 from the Institute of Hotel Management, Bhopal (India), and back then, L\&D managers in hotels 
The L\&D manager narrates her journey through 15 years of personal learning, educational learning, and skills development, career planning and personal endeavours. These reflective responses are based on direct experience, exploring and making sense of her identity, memories, understandings and feelings (though these are not explicit). She sets the circumstances surrounding the reflection'- It happened over a cup of tea while I was planning to resign from my last job. It appears to us, as readers of this account, that reflective practice can help bring to the surface the in-depth views of the reflector. This agrees with Bolton and Delderfield (2017: 1), who postulate that 'reflective practice is a state of mind, an ongoing attitude to life and work.' The subject's inability to immediately enter the L\&D function in a hotel environment did not preclude her from achieving her intention of becoming an L\&D professional. 
In addition, the reflection appears to demonstrate gradual reflection patterns. Gradual reflection patterns have both reflection and reflexivity which impact the reflector's accounts, for instance, on how she experienced many challenges. Johns (2017) maintains that reflexivity helps 'looking back' to see self-becoming, in the sense of realising desirable practice set against an analysis of forces that have constrained, evidenced through a chain of experiences whereby one link of the chain leaves a thread that is picked up and developed by next link. On the one hand, the reflector seems to relish in her intent of joy. It seems to the reader that self-reflection has a component of joy, a sense of achievement and liberation. It is an in-depth review of events (Bolton and Delderfield, 2017). This enables the practitioner to find routes through difficulties, dilemmas, and decision making. On the other hand, reflexivity is concerned with self-critical reflection. It focuses upon one's actions, thoughts, hopes, fears, roles, values and assumptions, to gain insight into them. Yet, we believe that more than improving reflection and reflexivity, the reflective practice offers the reflector a gradual reflection pattern that expresses a sense of achievement, self-fulfilment and brings insight to the wider circumstances surrounding the reflection.

\section{The L\&D manager's reflection on her educational journey}

Arguably, practice, and its attendant education and research, primarily concerns individual people. Education is also concerned with times and spaces and impacts professional growth.

The choice of studying further was completely self-driven and funded. It came from constantly wanting to learn and give back to my teams at work. L\&D in India is still at a very developmental stage, and the concept of talent management is starting to make its way to our organisations.

The reason I chose a course with the University of Edinburgh was to gain a deeper understanding of $L \& D$ in a developed country, and this was with one of the best universities in the world. I was assured, coming from another country, that I would be exposed and challenged to some of the best content and teachers in the industry. I was clear about going through a full-time course to make full use of my learning. 
Another key factor of the course was providing a work-based learning opportunity as a part of the course curriculum. I had worked for almost five years before I took on the course and knew the relevance of putting theories into practice and keeping these to the fore, so you don't forget them. That added to my experimental learning and is something I still use in my current role.

It appears that the reflector adopts a cognitive learning theory (Piaget, 1954; Marton and Ramsden, 1998) whereby learning is a qualitative change in a person's way of seeing, experiencing, understanding, or conceptualising something in the real world. It can be argued, therefore, that the reflector senses a change in her environment and sets purposefully to make the desired change. For example, she is 'self-driven', 'wanting to learn', 'giving back to her team', and can 'contribute to the development of her profession in her country'. The subject's reflection, therefore, demonstrates that learning is a process of active engagement with experience. 'It is what people do when they want to make sense of the world. It involves an increase in skills, knowledge or understanding, a deepening of values or capacity to reflect. Effective learning will lead to change, development and a desire to learn more' (Campaign for Learning, 2004). Furthermore, the reflector considers her experiential learning opportunity in a way that demonstrates that her knowledge is created through the transformation of experience. Reflection and learning are therefore interrelated, and through reflective practice, learning is deepened but also resonates in changes observable to the reflector as evident in her reflections. We conclude that from reflective practice, the motivation underpinning the learning of the reflector emerges.

\section{The L\&D manager's reflection strategic dimensions of change and its impact on a professional career}

Change is a beautiful action, and without this, I don't think I would have learnt as much as I have in the last 15 years. I have changed industries, careers and roles, and yet continued to develop as an individual. Even in my current role, I have experienced changes in our vision and mission, and then internally, I have gone through changes from my direct line manager through to the role itself. I joined my current employer as 
an L\&D manager for one of their hotels in Bangalore, and within less than a year and a half, I took on an additional role of managing $L \& D$ for the Indian region too. So, my professional goals changed, and the way I operated changed, from being an $L \& D$ manager for a hotel to taking on the larger responsibility of managing the region.

The L\&D manager recognises the changes happening within her context, acknowledges its impact on her 'changing industries, careers and roles' and finds herself in career learning (Lengelle, et al., 2013). We propose that autobiographical reflective stories based on direct experience, exploration and sense-making improve the reflector's understanding and allow the reflector to refocus on her career path and personal growth within her career. From this, it is possible to conclude that gradual reflective patterns, coupled with autobiographical narrative, can enhance reflective practice, illuminating the career learning requirements of the reflective practitioner. This enables the interpretation of the reflection to continue to influence change. This, in turn, leads to the fulfilment of the reflection.

I have always been very open to change, as I knew that's the way to personal development and learning. When I joined my current organisation, the processes at property level needed change, and similarly, when I took on the role of L\&D Manager - India, there were changes I needed to bring in to the team to increase team engagement, as we are spread throughout 8 different locations. Both changes needed people's engagement and acceptance in order for them to succeed.

At the hotel level, to change the current processes, I needed key stakeholders to be involved. During my leadership workshops, I started to involve the heads of departments to come and talk about their work and how they impact the business. It got them engaged, and at the same time team members understood the operational aspects with real examples. I continue to use 'challenge team' with the way my learning programme workshops are delivered.

At the country level, I knew I had to work towards aligning the L\&D objectives across the different locations and provide more support to new L\&D managers. When I had joined the company, I felt a little lost and could have done better with strong support and guidance into the system. After taking on the current role, I knew I needed to create a system of strong support for all L\&D managers, especially new ones. 
Critical reflective practice requires three important aspects, as argued by Fay (1987); curiosity, commitment and intelligence. The L\&D manager appears to be demonstrating two of these aspects in her reflection. Concerning commitment, the L\&D manager understands the need to engage with her stakeholders, involving the head of departments, but also recognises what might engage these stakeholders, and sets about to 'talk about their work and their impact on the business'. This is an insightful approach to exhibit commitment to stakeholders by valuing their work. With regard to Fay's (1987) intelligence aspect, the L\&D manager determines her 'intelligence' by adapting to her situation after feeling 'a little lost' may be of her capabilities or due to the changes in her environment. This is an evocative occasion as defined by Bolton and Delderfield (2017), and as such, evocative situations such as feeling, 'a little lost' play an important part in narrating reflection practice. We can also conclude from this that the fulfilling of the reflection is embedded in curiosity, commitment and skilful intelligence of stirring her colleagues.

\section{The L\&D manager's reflection on organisational politics}

The big question for all managers is about managing politics. Politics is the process whereby 'actors' attempt to structure a situation where their individual goals are promoted (MacMillan, 1978)

Politics is very common in any organisation, and it is very rare for any organisation to not be affected by it. Over the years, I have learnt the best way to deal with any politics is numbers (data) and patience. I continue to make sure that my work delivers what is expected of my role and I am able to present the data wherever possible.

To continue to integrate my learning without annoying people, I knew that I needed them to know what, why and how of what I was doing. I started to engage different key stakeholders by delivering workshops. This gave them an understanding of the changes I was trying to bring. Once they started becoming part of the learning interventions, it was easy, and they started to enjoy the process. However, it didn't happen overnight, and it took patience and constant support. 
Fook and Askeland (2006) assert that reflexivity involves being aware of our context. In political terms, sensing the power base and the interests of stakeholders is an important tool. This brings in Fay's (1987) third component of critical reflective practice, 'intelligence', which helps to clarify professional issues and power struggles. Not only does reflective practice improve the worldview of the reflector, but it also helps in achieving awareness of the worldview of the reflector's stakeholders, enhancing their self-understanding.

\section{The L\&D manager's reflection on being a better manager}

In my last five years as a manager, there are various key learning aspects I have experienced and have made me what I am today as I continue to learn. However, there are two key learning aspects I would emphasise highly-patience and communication. Dealing with different key stakeholders based across geographical boundaries sometimes can be a very frustrating task. Also, not everyone comes with an invested vision in $L \& D$. For them, it is often perceived as just another function that does not add any value.

I have learnt that patience is the key when it comes to dealing with people who are not invested, along with communication. There should be constant communication about the value that leadership and talent development add to day-to-day operations, discussions about numbers, guest feedback, etc., in a way that shows the ROI in terms of behavioural changes. This process can be long and frustrating at the same time, and keeping calm and patient has shown results. I have also seen people coming on board now after good two-plus years of effort in my current role.

There is powerful evidence that learning is a key factor in improving a manager's ability. The underpinning ingredients in achieving this are 'patience and communication' in dealing with various stakeholders. Bassot (2016) suggests that in professional practice, reflexivity means we are aware of how we think, feel and act and the assumptions we might be making. It appears that geographically dispersed stakeholders require different approaches to communication. In addition, reflexivity raises awareness concerning issues of power within organisations (Bassot, 2016), and constant interaction with stakeholders gives a better meaning to the function of 
L\&D. It also contributes to gaining wider approval and increasing the reputation of the profession.

\title{
The L\&D manager's reflection - seeing the big picture
}

\begin{abstract}
When I look back at the last three years, a lot has happened, and I have grown exponentially about skills and competencies. There are three key components I would continue to use and focus upon to be a better leader:

Investment of the stakeholder - I deal with stakeholders across a wide geographical region, and sometimes I don't see them for months and years. However, I needed to ensure they were invested (general managers and human resources managers/director human resources) in what we do as a team (L\&D managers). I involve the stakeholders from the planning stage, so they are engaged throughout the process and are aware of the details. I continue to collaborate at different levels for regional or property based on needs. An example of this is that we use GMs to run our leadership workshop while I co-facilitate it, and with the management trainee selection process, the GM and $H R M / H R D$ s are involved at every stage.
\end{abstract}

Communicate - I believe good communication can build a strong relationship. I learnt that people just want to be kept informed of what's going on. Hence, I continue to make sure information is communicated either through emails or webinars to the relevant audience. After taking on my role, my focus was to communicate whenever I had an opportunity to, in addition to regular telephone conversations. During my conversations, I would always try to understand what it is that they expect the $L \& D$ managers at their hotel to achieve and what support they need from me to develop their teams. Now, after over a year, I can see the difference and the engagement of stakeholders.

Action planning - As an L\&D manager for a hotel in India, I am constantly moving between both the roles and their requirements. Every day, something new comes up and needs immediate attention for a positive outcome. I must have action plans for different activities and people involved. This helps in identifying the growth and change, along with the people's reaction. In a changing industry, like hotels, we are always moving from one project to a second and another. Without a strong action plan, effectiveness and productivity would be difficult to measure.

Schön (1983) argues that through reflection, a practitioner can bring to the surface and then criticise the tacit understandings that have grown up around the repetitive experiences of specialised practice and make new sense of the situation of uncertainty or uniqueness they may 
allow themselves to experience. It seems that the L\&D manager (reflector), through the longstanding challenges experienced, has adopted a new mental model that is a conceptual system ('invest in stakeholders', 'communication' and 'action planning'). This insight into the reflector's worldview is essential in understanding what makes the reflector a successful practitioner. We postulate that this worldview functions as an interpretive conceptual scheme to explain how the reflector has grown as an L\&D professional practitioner. The research subject ultimately believes in investing in stakeholders, communication and planning.

\section{The L\&D manager's reflection - status of L\&D to professional status in her context}

I see my role as more of a leader and coach than just a manager. Our hotels are known for the millennials we have working with us, and the way one manages that generation is very different than Gen X, Z, or baby boomers. Following is a summary of my learning:

- Build trust by creating open communication

- Constantly look for ways to develop the team and empower them

- Engage each stakeholder in whatever way you can

- Provide opportunity and let people create their growth path

- Be a good listener

Being a good leader today within the hotel industry is all about open communication, accepting new ideas and being ready for change. The generation has changed, be it employees or travellers, and that demands a very innovative approach towards learning and talent development. The way we grow our people reflects on how they are treating our guest and guest experience.

There is constant work that is currently being done to highlight the contributions made by L\&D managers in the region to date. Also, there are key leadership programmes that we run across the region, and they are directly linked to their promotion. For example, to become Director of Operations, Mr A must go through programme ABC. We closely monitor the participants from these programmes, and whenever there is an opportunity, these people are given the first chance to apply for that position. Our MT programme is closely monitored by the hotel's L\&D managers, and we have been doing very well with the outcomes of the programmes. It still has a long way to go in this country. Our leaders need to start looking at L\&D as a business partner and not just a cost centre. They need to see the long-term impact that any $L \& D$ intervention has in a company's growth. 
The L\&D manager appears to be self-identifying as a leader and coach whose mission is to help develop talent and improve other people's capabilities, skills and abilities through a series of interventions. It seems to us that reflective practice improves the reflector's capability to understand her performance. The L\&D manager infuses standards of work, encourages collegiate control and has a privileged position, laying special claim to a particular body of knowledge and/or set of technical competencies, and this is a clear demonstration of a level of professional consciousness.

\section{Discussion}

This study used reflective practice narratives to explore how reflective practice improves the L\&D professional's growth and the L\&D function. The reflective practice works as a continuous interplay between inference and observation, and it is very much a conversation between the L\&D manager and her work context (Clarà, 2015). Our interest in researching this has led us to unearth the importance of reflective practice in creating a deeper and more meaningful sense of awareness of one's work context (Fook and Askeland, 2006). Further, we argue that reflective practice materialises through five main gradual reflective patterns. These include the circumstances surrounding the reflection, the content of the reflection, the interpretation of the reflection, the fulfilling of the reflection in exploring the career development path and the learning and changes experienced by the L\&D manager. We, therefore, agree with Erlandson and Beach (2008) that there are two paradigms in reflection. First, reflection could be seen as a theoretical inclusion which signals the gradual philosophical patterns and the interpretation of new logical thought process. Second, reflection could be used as an open space for idea exploration. This in effect stipulates the awareness of one's context regarding the coherent exploration of career development plan and pathway as well as the learning experiences of the L\&D manager. This paper asserts that the pre-structured semiinterview questionnaire and narratives derived from the recordings have deepened the 
experience of the L\&D professional and further augmented the quality of individual reflection. This concurs with Griffits and Tann (1992, p.71) who state that we should value practitioner's theories and encourage them to make explicit tacit theory to help theorise from their practice at several different levels of reflection. This is critical because it demonstrates how the professional life of the L\&D manager reflects on the type of training deemed appropriate to support the human capital development initiatives at the organisational level. As personal theories could be revealed at different levels, idiosyncrasies in ideologies could be scrutinised, challenged, compared to public theories, and then confirmed or reconstructed based on the contextual issues facing the organisation. The personal and public theories of individuals who occupy key positions in organisations need to be viewed as living, intertwining tendrils of knowledge which grow and feed into practice. Based on this philosophical standpoint the next section presents our key contributions to theory and practice.

\section{Theoretical and practical contributions}

At a theoretical level, as reflective practice offers the practitioner a 'gradual reflection pattern' that expresses a sense of achievement, self-fulfilment and the circumstances surrounding the reflection, we put forward the idea that from what reflective practice reveals, the motivation underpinning the learning of the reflector can emerge giving coherent solutions to incoherent and unclear decisions (Clarà, 2015). Therefore, the function of reflective practice is to transform complicated situations to be in greater harmony with corporate goals (Dewey, 1933, p.195). We argue that thinking and learning are interrelated and through reflective practice, knowledge deepens but also results in changes observable to the reflector and to subordinates or those who depend on his/her role to achieve organisational outcomes. Besides, we find that gradual reflective patterns coupled with autobiographical narrative can enhance reflective practices. This according to Schön (1983) illuminates the learning requirements of human resource management professionals. This enables the interpretation of the reflection to continue 
to influence organisational change. Fulfilling the reflection involves underlying curiosity, commitment and the skilful intelligence of achieving buy-in from colleagues. In this context, reflective practice improves the worldview of the reflector, but it also helps in achieving awareness of the worldview of the reflector's stakeholders, enhancing their self-understanding. Moreover, insight into HR practitioners' worldview is essential to an understanding of what makes them successful. More importantly, the worldview functions as an interpretive conceptual scheme that explains how the subject has grown as an L\&D professional practitioner. The reflector believes in investing in stakeholders, communication and planning. These findings are in line with Fay (1987) who argued that HR practitioner's reflective practice improves the capability to understand others by identifying ways to improve their performance

This research contributes to the L\&D literature by demonstrating that reflective practice promotes the L\&D function is an essential part for effectively understanding different cultural and institutional contexts by localising and integrating the relevant human resource management systems and practices within firms that operates in different countries (Adams et al., 2017). At the practice level, the personal narratives and the reflections of L\&D managers present how managers in general de-construct and constructs their professional acumen and personal growth.

\section{Limitations and further research}

Whilst the sampling strategy is purposive and opportunistic, it is not possible to generalise statistically from it. However, we still believe that the raw material of the narrative analysis is the multiple modes of representation used to reference and make sense of human experience (Floersch, and Longhofer, 2010). Furthermore, since the research aims to understand the ways in which reflective practice can enable the $L \& D$ practitioner to promote the $L \& D$ function in an organisation in the hotel industry in India, we suggest that further research could be carried 
out across the broader spectrum to investigate the impact of the reflective practice on senior managers in the same industry and to understand how they could leverage resources to support the L\&D function. One might, for instance, examine how discursive psychology impacts on reflection, adopting the discursive action model (Wetherell, 2003) to: explore how action focused the reflection is, or how remembering and attribution are used in the reflection process. One might also focus on how reflectors use facts and interests in their reflections. Finally, this study claims that reflective practice materialises through gradual reflective patterns, one might also want to examine how reflectors' accounts of events routinely attend to issues of agency and personal accountability as a discursive practice.

\section{Conclusion}

The purpose of this study has been to contribute to the clarification of how (L\&D) professionals use reflective practice to promote the function of $L \& D$ and their professional growth. We find that reflective practice enhances the awareness of the context of the reflection which emerges through gradual reflective patterns such as the circumstances surrounding the reflection, the content of the reflection, the interpretation of the reflection and the fulfilling of the reflection. Generally, this enables HR practitioner's ability to explore the career development paths but also for meeting HRM needs within organisations. Pertaining to this study is also the idea that reflective practice works as a continuous interplay between inference and observation throughout narrative developments. We believe that these findings contribute to the clarification of the ways in which L\&D managers could create their personal story and theory within different cultural and institutional settings.

\section{References}

Abbott, A. (1991). The order of professionalization: an empirical analysis, Work and Occupation, 18, pp.355-384. 
Adams, K., Nyuur, R. B., Ellis, F. Y., \& Debrah, Y. A. (2017). South African MNCs' HRM systems and practices at the subsidiary level: Insights from subsidiaries in Ghana. Journal of International Management, 23(2), 180-193.

Arnold, L. and Stern, D.T. (2006) What is medical professionalism? In Stern, D.T. (ed.) Measuring Medical Professionalism, Oxford: Oxford University Press.

Bager-Charleson, S. (2010) Reflective practice in Counselling and Psychotherapy, Exeter, Learning Matters.

Bassot, B. (2016) The Reflective Practice Guide: an interdisciplinary approach to critical reflection, London, Routledge.

Beard, C., Wilson, J. and Beard, C. (2006) Experiential learning, London, Kogan Page.

Bleakley, A. (1999) From Reflective Practice to Holistic Reflexivity, Studies in Higher Education, 24(3), pp.315-30.

Bolton, G. (2009) Writing values; reflective writing for professional development, The Lancet, 373, 201.

Bolton, G., Delderfield R. (2017) Reflective Practice: Writing and Professional Development, $5^{\text {th }}$ ed., London, Sage.

Boud, D., Keogh, R., Walker, D. (1985) Promoting reflection in Learning: a Model, in D. Boud, R. Keogh, and D. Walker (eds.) Reflection: Turning Experience into Learning, London, Kogan Page.

Boyd, E. and Fales, A. (1983) Reflective learning: key to learning from experience, Journal of Humanistic Psychology, 23(2) pp.99-117.

Boydell, T. and Leary, M. (2003) Training Essentials: Identifying Training Needs, London CIPD.

Brookfield, S.D. (2009) Engaging critical reflection in corporate America, in J. Mezirow and E.W. Taylor (eds) Insights from Community, Workplace, and Higher Education Publisher: JosseyBass.

Brunt, P., Horner, S., and Semley, N. (2017) Research Methods in Tourism, Hospitality and Events Management, London, Sage.

Caldwell, R. (2003) The changing roles of personnel managers: old ambiguities, new uncertainties, Journal of Management Studies. Vol 40, No 4, pp.983-1004.

Campaign for Learning (2004) https://www.campaign-for-learning.org.uk/our-approach [Accessed $11 / 11 / 2017]$

CIPD (2017) HR professionalism: what do we stand for? London, Research Report CIPD: https://www.cipd.co.uk/Images/hr-professionalism-what-do-we-stand-for_2017_tcm1817960.pdf [accessed, 19/03/18]

Clarà, M. (2015). What is reflection? Looking for clarity in an ambiguous notion. Journal of teacher education, 66(3), 261-271.

Clydesdale, G. (2016) Management education: reflective learning on human interaction, European Journal of Training and Development, 40 (5), pp.286-301.

Dewey, J. (1993) How we think, J.C. Heath, Boston. Macmillan.

Duncan, Margot. Autoethnography: Critical appreciation of an emerging art. International journal of qualitative methods 3.4 (2004): 28-39.

Erlandson, P., \& Beach, D. (2008). The ambivalence of reflection-rereading Schön. Reflective Practice, 9(4), 409-421.

Evetts, J. (2003) The sociological analysis of professionalism: occupational change in the modern world, International Sociology, Vol 18, No 2, pp.395-415.

Finlay, L. (2008) Reflecting on reflective Practice, PBPL paper 52, Milton Keynes, Open University. 
Fook, J. and Askeland, G.A. (2006) The "critical" in critical reflection in S. White, J. Fook, and F. Garder (eds.) Critical Reflection in Health and Social Care. Maidenhead, Open University Press/McGraw-Hill Education.

Francis, H. and Cowan, J. (2008) Fostering an action-reflection dynamic amongst student practitioners, Journal of European Industrial Training, 32 (5), pp.336-346.

Garavan, T.N. (1991) Strategic Human Resource development, Journal of European Industrial Training, 15 (1), pp. 17-30.

Garavan, T.N., McGuire, D., and Lee, M. (2015) Reclaiming the 'D' in HRD: A typology of Development conceptualisations, Antecedents and Outcomes, Human Resource Development Review, 14(4) pp.359-388.

Ghadirian, F., Salsali, M., Cheraghi, M.A. (2014) Nursing professionalism: an evolutionary concept analysis. Iranian Journal of Nursing and Midwifery Research 19(1): 1-10.

Gibbs, G. (1988) Learning by doing: a guide to teaching and learning methods, Further Education Unit, Oxford Polytechnic, Now Oxford Brookes University.

Gillham, B. (2000) Case Study Research Methods, London, New York: Continuum.

Gilmore, S. and Williams, S. (2007) Conceptualising the 'personnel professional': a critical analysis of the Chartered Institute of Personnel and Development's professional qualification scheme. Personnel Review, Vol 36, No 3, pp.398-414.

Griffiths, M., \& Tann, S. (1992). Using reflective practice to link personal and public theories. Journal of Education for teaching, 18(1), 69-84.

Harrison, R. (2009) Learning \& Development, $5^{\text {th }}$ ed., London, CIPD.

Jasper, M. (2013) Beginning reflective practice, Andover, Cengage Learning.

Khurana, R., Nohria, N. and Penrice, D. (2004) Management as a profession, Working papers, Cambridge, MA: Centre for Public Leadership, pp.4-14.

Kinsella, E.A, and Pitman, A. (2012) Engaging phronesis in professional practice and education. Phronesis as professional knowledge. SensePublishers, Rotterdam, 2012. 1-11.

Kolb, D. (1984) Experiential Learning: experience as the Source of Learning and Development, Upper Saddle River, NJ, Prentice Hall.

Kolb, D. (2014) Experiential learning: Experience as the source of Learning and Development, $2^{\text {nd }}$ ed. New Jersey, Pearson Education Inc.

Laslett, Barbara. (1999) Personal narratives as sociology. Contemporary Sociology, pp. 391-401.

Lawrence, T.B. (1999) Institutional strategy, Journal of Management, 25, pp.161-188.

Lengelle, R., Meijers, F. Poell, R., and Post, M. (2013) The effect of creative, expressive, and reflective writing on career learning: An Explorative study, Journal of Vocational Behaviour, 83, pp.41927.

Maaranen, K., \& Stenberg, K. (2017). Portraying reflection: The contents of student teachers' reflection on personal practical theories and practicum experience. Reflective Practice, 18(5), 699-712.

MacMillan, I. C. (1978). Strategy Formulation: political Concepts, St Paul. MN,West Publishing.

Marton, F. and Ramsden, P. (1988) What does it take to improve learning? in P. Ramsden (ed.) Improving Learning: New Perspectives, London, Kogan Page.

Mason, J. (2018) Qualitative Researching, $3^{\text {rd }}$ ed., London, Sage.

Mayo, A. (2003) Training Essentials: Creating Training and Development Strategy, London, CIPD.

McCall, M. (2004) Leadership development through experience, Academy of Management Executive, 18(3), pp.127-130.

McCray, J. and Warwick, R. and Palmer, A. (2018) Impressions of action and critical action learning: exploring the leadership development of senior doctors in an English healthcare organisation, International Journal of Training and Development, 22:1. 
McIntyre, Cindy, Judith Lathlean, and Jorge E. Esteves. Reflective practice enhances osteopathic clinical reasoning, International Journal of Osteopathic Medicine 33 (2019): 8-15.

Mercurio, Z.A. and Korte, R. (2017) Pragmatism and HRD: Practical Foundations for Research, Theory, and Practice, Human Resource Development Review, 16(1), pp.60-84.

Merirow, E.W. Taylor and Associates (eds.) Transformative Learning in Practice: Insights from Community, Workplace and Higher education, San Francisco, CA, Jossey-Bass, pp.125-36.

Messmann, G. and Mulder, R.H. (2015) Reflection as a facilitator of teachers' innovative work behaviour, International Journal of Training and Development, 19:2

Mizirow, J. (1981) A critical theory of adult learning and education, Adult Education, 32(1), pp.3-24.

Nansubuga, F., Munene, J.C. and Ntayi, J.M (2015) "Can reflection boost competences development in organizations?, European Journal of Training and Development, Vol 39 (6), pp.504-521

Osgood, J. (2006) Deconstructing professionalism in early childhood education: resisting the regulatory gaze, Contemporary Issues, 7,1.

Piaget, J. (1954) The Construction of Reality in the Child, New York, Basic Books.

Poth, C.N. (2018) Innovation in Mixed Methods Research: A Practical Guide to Integrative Thinking with Complexity, London, Sage.

Reeves, Scott, Ayelet Kuper, and Brian David Hodges. Qualitative research methodologies: ethnography, BMJ 337 (2008): a1020.

Rigg, C. and Trehan, K. (2008) Critical reflection in the workplace: is it just too difficult?, Journal of European Industrial Training, 32 (5), pp.374-384.

Rigg, C. Trehan, K., and Stewart, J. (2008) Critically Reflective Practice in Human Resource Development: Critically Reflective practice in human resource Development, Journal of European Industrial Training, (32) 5, p.322.

Sambrook, S. and Stewart, J. (2008) Developing critical reflection in professional focused doctorates: a facilitator's perspective, Journal of European Industrial Training 32 (5), pp.359-373.

Sambrook, S. and Stewart, J. (2010) Teaching, learning, assessing HRD: findings from a BMAF/UFHRD research project, Journal of European Industrial Training, 34 (8/9), pp.71034.

Schön, D.A. (1983) The Reflective Practitioner: How Professionals Think in Action, New York, Basic Books.

Schön, D.A. (1987) Educating the Reflective Practitioner, San Francisco, CA: Josey-Bass

Smith, T.L., Barlow, P.B., Peters, J.M. and Skolits, G.J. (2015) Demystifying reflective practice: using the DATA model to enhance evaluators' professional activities, Evaluation and Program Planning, 52, pp.142-7.

Stahlke Wall, Sarah. Toward a moderate autoethnography, International Journal of Qualitative Methods 15.1 (2016): 1609406916674966.

Stewart, J., Keegan, A., and Stevens, P. (2008) Postgraduate education to support organisation change: a reflection on reflection, Journal of European Industrial Training, 32 (5), pp.347-358.

Swan, E. (2008) Let's not get too personal: critical reflection, reflexivity and the confessional turn, Journal of European Industrial Training, 32 (5), pp.385-399.

Swanson, R.A. and Holton, E.F. III (2009) Theory of human resource development. In Foundations of human resource development ( $2^{\text {nd }}$ ed., pp. 97-111) San Francisco, CA, Brerrett-Koehler.

Tarrant, P. (2013) Reflective Practice and Professional Development, London, Sage.

Vollbrecht, S. and Bowerman, J. (2004) Managerial Learning: Changing times for medical laboratory managers: a personal experience, International Journal of Health Care Quality Assurance incorporating Leadership in Health Service. 17(4), pp.9-15.

Vollmer, H.M. and Mills, D.L. (1996) Professionalisation, Englewood Cliffs, New Jersey.

Wetherell, M., Taylor, S., \& Yates, S. J. (2001). Discourse theory and practice: A reader. Sage. 
Zibrik, K.J., MacLeod, M.L., Zimmer, L.V. (2010) Professionalism in rural acute-care nursing. Can J Nurs Res 2010; 42(1): 20-36. 
3 Table 1: Studies published on reflective practice from 2008 - 2019 in The Journal of European Industrial Training

\begin{tabular}{|c|c|c|c|c|c|}
\hline 5 & Authors/year & Titles/types & Findings & Originality/value & Research design methods \\
\hline $\begin{array}{l}7 \\
8 \\
9 \\
10 \\
1 \\
12 \\
13 \\
14 \\
13\end{array}$ & $\begin{array}{l}\text { Greg Clydesdale } \\
\text { Volume: } 40 \text { Issue: } 5 \text {, } \\
2016 \\
\\
\\
+ \\
5\end{array}$ & $\begin{array}{l}\text { Management education: } \\
\text { reflective learning on } \\
\text { human interaction } \\
\text { Paper type: Technical } \\
\text { paper }\end{array}$ & $\begin{array}{l}\text { a) analysis in the first journal instalments was } \\
\text { limited, and students regularly found negative } \\
\text { characteristics in colleagues. } \\
\text { b) students regularly found and showed an } \\
\text { understanding of the characteristics in themselves } \\
\text { and others. } \\
\text { c)they also put more thought into how to manage } \\
\text { those traits. The model provided a solution to the } \\
\text { problems of marking reflective journals. }\end{array}$ & $\begin{array}{l}\text { This paper contributes to } \\
\text { management education by suggesting } \\
\text { a method for enhancing both } \\
\text { relationship skills and self-awareness. }\end{array}$ & $\begin{array}{l}\text { A journal is used in combination with a } \\
\text { model of human nature. The model lists } \\
\text { human characteristics the management } \\
\text { trainees must identify in themselves and } \\
\text { others they interact. Students kept a journal } \\
\text { and analysed their interactions in reference to } \\
\text { a list of human characteristics. }\end{array}$ \\
\hline $\begin{array}{l}1 \\
1 \\
1 \$ \\
1 \\
20 \\
21 \\
21\end{array}$ & $\begin{array}{l}\text { Florence Nansubuga, } \\
\text { John C Munene, Joseph } \\
\text { M Ntayi (2015) Volume: } \\
39 \text { Issue: } 6,2015 \\
\end{array}$ & $\begin{array}{l}\text { Can reflection boost } \\
\text { Competences development } \\
\text { in } \\
\text { organizations? } \\
\text { Type: Research Paper }\end{array}$ & $\begin{array}{l}\text { The results showed that reflection and operant } \\
\text { competences correlate significantly. Second, there } \\
\text { was a larger effect size between the pre-test and } \\
\text { post-test assessment results for the } \\
\text { treatment group, implying a change in reflective } \\
\text { practice and acquisition of operant competences. }\end{array}$ & $\begin{array}{l}\text { The research adds value to the } \\
\text { existing competence development } \\
\text { frameworks by introducing reflective } \\
\text { practice among managers to create } \\
\text { competences that are compatible with } \\
\text { the operational context. }\end{array}$ & $\begin{array}{l}\text { A correlational design and a quasi- } \\
\text { experimental, non-equivalent group design } \\
\text { involving a baseline assessment (pre-test) of } \\
\text { participants' ability to reflect on their actions } \\
\text { instead of applying the standardized } \\
\text { competences. }\end{array}$ \\
\hline $\begin{array}{l}23 \\
24 \\
2 \$ \\
2 \$ \\
2 \$ \\
2 \$ \\
2 \$ \\
30\end{array}$ & $\begin{array}{l}\text { Jim Stewart, Anne } \\
\text { Keegan, Pam Stevens } \\
\text { (2008) Volume: } 32 \text { Issue: } \\
5,2008 \\
\end{array}$ & $\begin{array}{l}\text { Postgraduate education to } \\
\text { support organisation } \\
\text { change: a reflection on } \\
\text { reflection } \\
\text { Type: research paper }\end{array}$ & $\begin{array}{l}\text { Reflective journals were found to be an effective } \\
\text { tool for students who are practitioners involved in } \\
\text { organisational change through their capacity to } \\
\text { promote deep rather than surface learning. An } \\
\text { unintended outcome of the study was the } \\
\text { recognition that reflective practice in postgraduate } \\
\text { education supports the skills required to develop } \\
\text { the "thinking performer." }\end{array}$ & $\begin{array}{l}\text { The analysis has encouraged further } \\
\text { research into the development of } \\
\text { critical reflection, the use and } \\
\text { benefits of learning journals and more } \\
\text { specifically, how educators can } \\
\text { develop sufficiently robust } \\
\text { assessment criteria for such journals }\end{array}$ & $\begin{array}{l}\text { Assessment criteria were developed from the } \\
\text { literature on reflective practice and } \\
\text { organisational power and politics and mapped } \\
\text { against the content of the journals to } \\
\text { understand how and why students benefitted } \\
\text { from keeping the journals. }\end{array}$ \\
\hline 3 & $\begin{array}{l}\text { Clare Rigg, Kiran Trehan } \\
\text { Volume: } 32 \text { Issue: } 5 \text {, } \\
2008 \\
\end{array}$ & $\begin{array}{l}\text { Critical reflection in the } \\
\text { workplace: is it just too } \\
\text { difficult? } \\
\text { Type: case study }\end{array}$ & $\begin{array}{l}\text { The account illustrates difficulties of employing } \\
\text { critical reflection within the workplace arising } \\
\text { from the more complex power relations between } \\
\text { the multiple stakeholders in a commercial } \\
\text { context. In particular, dissonance provoked by } \\
\text { critical reflection confronts the client with tension } \\
\text { over whether to see organisation members } \\
\text { primarily as customers to please or as participants } \\
\text { in a change process which inevitably will disrupt }\end{array}$ & $\begin{array}{l}\text { The paper presents a rare account of } \\
\text { employing critical reflection in a } \\
\text { work organisation development } \\
\text { programme. }\end{array}$ & $\begin{array}{l}\text { A case study approach is taken, presenting an } \\
\text { empirical account } \\
\text { of a management and organisational } \\
\text { development programme that integrated } \\
\text { action learning and } \\
\text { critical reflection. }\end{array}$ \\
\hline
\end{tabular}




\begin{tabular}{|c|c|c|c|c|c|}
\hline $\begin{array}{l}4 \\
5 \\
6 \\
7 \\
8 \\
9 \\
10\end{array}$ & $\begin{array}{l}\text { Sally Sambrook, Jim } \\
\text { Stewart, Volume: } 32 \\
\text { Issue: } 5,2008\end{array}$ & $\begin{array}{l}\text { Developing critical } \\
\text { reflection in professional } \\
\text { focused doctorates: a } \\
\text { facilitator's perspective } \\
\text { Type: Case study }\end{array}$ & $\begin{array}{l}\text { Insights into how staff perceive critical reflection } \\
\text { within a DBA programme are offered, including } \\
\text { how staff might assume (incorrectly) that } \\
\text { advanced practitioners arrive with a high level of } \\
\text { maturity to engage in critical reflection, and yet } \\
\text { advanced practitioners "worry" about critique and } \\
\text { perceive it as negative and/or failure. }\end{array}$ & $\begin{array}{l}\text { Given the dearth of literature of } \\
\text { facilitating critical reflection in the } \\
\text { context of professionally focused } \\
\text { doctoral programmes, this paper } \\
\text { makes a small and initial contribution } \\
\text { to this } \\
\text { field. }\end{array}$ & $\begin{array}{l}\text { A selected finding from the perspective of } \\
\text { staff through their own critical reflections, } \\
\text { drawing on the data from the two away days } \\
\text { and the UFHRD workshop. Detailed } \\
\text { handwritten notes were taken and transcribed, } \\
\text { in addition to flipchart material provided by } \\
\text { the participants. These qualitative data are } \\
\text { analysed using thematic analysis. }\end{array}$ \\
\hline $\begin{array}{l}1 \\
12 \\
13 \\
14 \\
15 \\
10 \\
12\end{array}$ & $\begin{array}{l}\text { Helen Francis, John } \\
\text { Cowan } \\
\text { Volume: } 32 \text { Issue: } 5 \text {, } \\
2008 \\
\end{array}$ & $\begin{array}{l}\text { Fostering an action- } \\
\text { reflection dynamic } \\
\text { amongst student } \\
\text { practitioners } \\
\text { Paper type: Conceptual } \\
\text { paper }\end{array}$ & $\begin{array}{l}\text { Argues that achieving an alignment between the } \\
\text { development and assessment of student } \\
\text { capabilities is vital to the development of critical } \\
\text { reflection and explains how the strategy presented } \\
\text { for CPD supports self-management of this } \\
\text { process. }\end{array}$ & $\begin{array}{l}\text { The self-managed process explored in } \\
\text { the paper is framed by a social } \\
\text { approach to learning that places peer } \\
\text { interaction at the forefront of the } \\
\text { learning processes involved. }\end{array}$ & $\begin{array}{l}\text { The authors draw on their personal } \\
\text { experiences as a programme leader (Master's } \\
\text { in HRM) and an educational consultant to } \\
\text { describe their strategy for critically reflective } \\
\text { continuous professional development (CPD). }\end{array}$ \\
\hline $\begin{array}{l}1 \$ \\
19 \\
20 \\
21 \\
22 \\
23 \\
24 \\
2 \$\end{array}$ & $\begin{array}{l}\text { Elaine Swan } \\
\text { Volume: } 32 \text { Issue: } 5 \text {, } \\
2008\end{array}$ & $\begin{array}{l}\text { Let's not get too personal: } \\
\text { critical } \\
\text { reflection, reflexivity and } \\
\text { the } \\
\text { confessional turn } \\
\text { Paper type: Conceptual } \\
\text { paper }\end{array}$ & $\begin{array}{l}\text { a) Critical reflective practice might be understood } \\
\text { as an individualistic and individualising pedagogy } \\
\text { in spite of its claims to be critical. b) The } \\
\text { subjective and the self as an extension of the } \\
\text { feminist project of the personal is political - i.e. } \\
\text { that personal stories, feelings and issues have } \\
\text { social and political roots and consequences. c) } \\
\text { Reflection can be critical, leading to political } \\
\text { consciousness-raising. }\end{array}$ & $\begin{array}{l}\text { The paper brings new literature to } \\
\text { bear on the practice of critical } \\
\text { reflection and raises important } \\
\text { questions relevant to academics and } \\
\text { practitioners. }\end{array}$ & $\begin{array}{l}\text { The main approach is a review of key debates } \\
\text { in the literature on critical reflection and also } \\
\text { in the wider social sciences. }\end{array}$ \\
\hline
\end{tabular}


Manuscript ID EJTD-09-2019-0165

\section{Paper Title: " Enhancing professional growth and the learning and development} function through reflective practices: an autoethnographic narrative approach"

Dr Garavan Thomas

\section{Editor, European Journal of Training and Development}

\section{Authorial Response to Reviewers' Comments}

We are indeed grateful for the opportunity accorded us to revise and resubmit our paper to the EJTD. We have taken into full consideration the comments and have consequently revised the manuscript along with the suggestions made:

\section{Please expand the discussion section. Need more detail on future research implications. In}

\section{addition, the paper needs a short conclusion}

1. We have strengthened and also expanded the discussion section highlighting both the theoretical and practical contributions. This could be checked from pages 25-27.

2. We have clearly presented some interesting areas for future research and have also established research implications. This could be confirmed on page 27-28.

3. We have now provided a short conclusion focusing on how the awareness and context of reflection enable HR practitioners to explore career development pathways. This could be confirmed on page 28 .

We hope the revised version satisfactorily addresses all the concerns and comments of the reviewers.

Thank you and kind regards

Dr Serge Koukpaki

Dr Kweku Adams 